\title{
Journalism research: a dominant field of communication research in Spain. A meta-research on Spanish peer-reviewed journals (2000-2014)
}

\author{
Enric Saperas \& Ángel Carrasco-Campos \\ Espanha \\ E-mail: enric.saperas@urjc.es/angel.carrasco.camposesoc.uva.es
}

\begin{abstract}
Since the beginning of Democracy to the present day, "Journalism" has led Spanish communication research. This dominant presence has been especially important for the progressive internationalisation of Spanish research, which began during the early 2000 s through the implementation of methodological standards in empirical studies. This paper aims to describe how researchers have developed journalism research published by four source peerreviewed journals for Spanish communication stu-

tent analysis protocol has been designed and applied to a sample of 729 journal articles, of which $\mathrm{N}=360$ were focused on journalism, to observe the objects of study in this field, the modalities of research and the research techniques applied. The results show that even though empirical research in journalism studies is in a consolidation stage, mainly focused on content studies of the daily press, it is still far from a diversity of objects of study and from a methodological pluralism.
\end{abstract} dies during the period 2000-2014. A specific con-

Keywords: journalism; meta-research; Spain; peer-reviewed journals; research techniques; objects of study.

\section{Introduction}

COMMUNICATION research in Spain has developed in an institutional frame (universities, research centres, knowledge demands) significantly different to other European countries (Saperas, 2016), and in a political, social and economic context also different, due to the Dictatorship and to the Transition process to Democracy. Only during the early 1990s communication studies would leave this exceptional status, characteristic of a transitional society, and consolidate a

Data de submissão: 31-03-2018. Data de aprovação: 26-04-2018.

This work is part of the research project entitled "25 years of communication research in Spain (1990-2015): scientific production, academic community and institutional context", funded by the National Plan for Scientific and Technological Research and Innovation for 2013-2016 (CSO2013-40684-P, http://www.incomes-25.es). Principal Investigator (PI): Manuel Martínez-Nicolás.

A Revista Estudos em Comunicação é financiada por Fundos FEDER através do Programa Operacional Factores de Competitividade - COMPETE e por Fundos Nacionais através da FCT - Fundação para a Ciência e a Tecnologia no âmbito do projeto Comunicação, Filosofia e Humanidades (LabCom.IFP) UID/CCI/00661/2013.
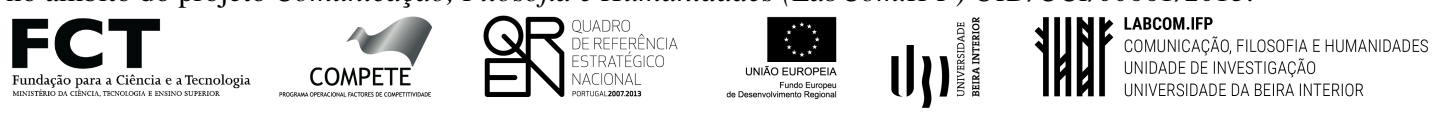
progressive and definitive trend towards international academic models, in terms of teaching activity (especially regarding other countries integrated into the European Higher Education Area - EHEA) and research procedures regarding the dissemination systems (peer-reviewed journals, scientific associations) and the methodological, theoretical and institutional standards.

The objective of this work is to observe how communication research is organised and structured in a dominant field: journalism research (Martínez-Nicolás \& Saperas, 2011). By continuing the research line developed in previous research, this paper aims to contribute to the examination of journalism studies in Spain. Therefore, the analysis focuses on a period of 15 years (20002014) on which communication and journalism research have experienced a consolidation process on three levels that distance from previous stages. On the one hand, this period refers to a stage of consolidation of peer-reviewed journals as reference institutions for the publication and dissemination of research. At the same time, this institutional transformation is complemented by a new academic and research context for the training and promotion of researchers through the creation of the evaluation agencies for research and teaching, and the establishment of the European Higher Education Area (in both cases, they draw new formative and professional trajectories in the academic career). Finally, as a consequence of this transformative period, and unlike other countries that had been research references until the nineties (France and Italy, for instance), communication research in Spain initiates a process of consolidation by adopting the methodological and theoretical standards that are dominant in northern and central Europe, and in Great Britain and the United States.

In sum, this study presents a study of journalism research, as it is the field that has widely dominated this transformation and international levelling of communication research. For this purpose, meta-research would provide an adequate perspective as it stands as a modality to observe, by a specific content analysis protocol, the core elements of research procedures. Therefore, and unlike other studies in this field, it is intended not only to observe a determining period in the consolidation of Spanish research, but also to describe how this research is operationalised. All of this, considering the present moment of changes in Spain regarding the media consumption transformations and the crisis of the professional journalistic market, as referential context for the selected period of analysis.

\section{Media, professional and institutional context of journalism research in Spain.}

\subsection{The media context and the employment crisis of communication and journalism profes- sionals (2008-2014)}

Since the end of the Dictatorship and the progressive incorporation into the European market, Spain has experienced a dynamic economic expansion that, despite the present crisis context, currently means the $10.3 \%$ of the economy of the Eurozone (Ministerio de Economía y Competitividad, 2017), with a growing media system of forty million of potential consumers $(44,518,432$ people over 14 years old in 2017, according the Spanish National Institute of Statistics ${ }^{1}$ ). Nowadays Spanish media system has become consolidated through the confluence of four dimensions of

1. Data available at: http://www.ine.es/jaxi/Datos.htm?path=/t20/e245/p08/10/\&file=02002.px 
structural change: the progressive universal access to the Internet and the arrival of smartphones, some significant variations in media consumption, the consolidation of a media model of polarized pluralism with strong political parallelism, and a deep crisis in the labour market of communication professionals (especially of journalism professionals). These four trends have shaped the current Spanish media system through two successive periods. The first takes place between 2000 and 2008, when the Internet became widespread and began its impact on conventional media and television (by means of the emergence of second screens). Above all, since 2006 the number of broadband connections increased continuously, and would consolidate with the universalisation of smartphones and, consequently, with a significant change in the telecommunications business. The consequence has been immediate, by the transformation of radio and television reception, the consolidation of social media, and the increase in the production and flow of images. A second period that began in 2008, the year of the outbreak of the economic crisis, when a second structural change happened, with great implications in the media consumption and the levels of media penetration in the Spanish population, especially the press, magazines and cinema.

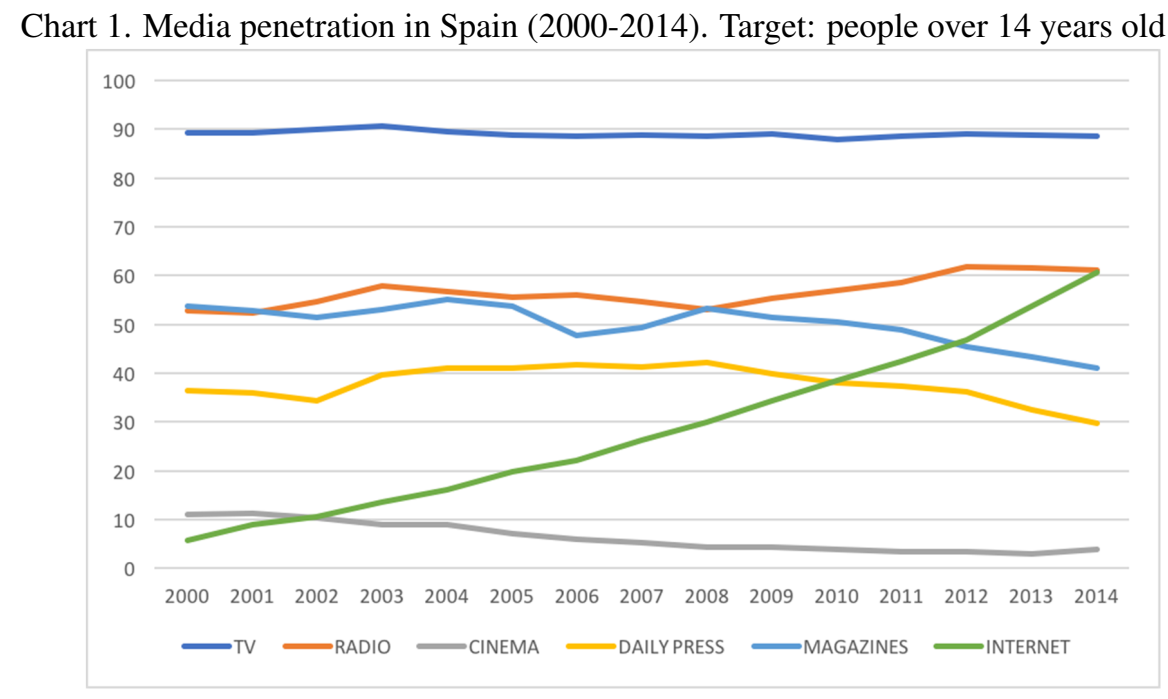

Source: Spanish Media Observatory (AIMC - Estudio General de Medios).

Those years, the Spanish media market was characterised by the hegemony of audiovisuals, except for the loss of consumption of cinema in movie theatres. The case of television as the dominant media (close to a $90 \%$ of penetration rate) is paradigmatic, especially compared to the significant decrease of newspaper (with a loss of 6.5\%) and magazines consumption rates (with a decrease of $12.6 \%$ ). On the other hand, chart 1 shows that the period of analysis of this study corresponds to the implementation of the Internet, with the increase of $51.1 \%$ in the penetration rate. In a third structural dimension, Spain developed a complex media system that fits the Polarized Pluralist Model typical from the Mediterranean Europe (Hallin \& Mancini, 2004, pp. 89-143) which initiated during the late 1980s by of the professionalisation of journalism (Ortega, 2003; Casero, 2012), a high level of political parallelism that implies a strong political and informative 
polarisation (González \& Novo, 2011; Casero, 2012; Mellado, Humanes et al., 2013; Mellado, Humanes \& Márquez-Ramírez, 2017), the centrality of politics in news agenda (López-Rabadán \& Casero, 2012), even with a low mediatization of politics (Martínez-Nicolás, Humanes \& Saperas, 2014) or, in short, a widespread survival among journalists of a "pragmatic-sacerdotal" attitude to political power, that is, in which journalists' self-image about their professional role determines the elaboration of the journalistic discourse in a more partisan way to condition the agenda (Van Dalen, 2012; Van Dalen, De Vreese \& Albæk, 2012). Finally, starting in 2008, another structural element that has characterised the communication professions and journalism in Spain is the employment crisis. According to the Federation of Associations of Journalists of Spain (FAPE) Crisis Observatory $^{2}$, between 2008 and 2015, a period that included in this study, there were 11,225 redundancies in the entire media system, of which 4,511 were in print journalism (FAPE, 2014, pp. 90-100). In 2014 (table 1), the year in which there were higher dismissal figures, journalism professionals worked basically in four media: daily press (34.9\%), television (36.5\%), digital media $(33.3 \%)$ and radio $(24.5 \%)$.

Table 1. Journalists hired in Spain, by media (2014)

\begin{tabular}{lc}
\hline Media & $\begin{array}{c}\text { Hiring } \\
(\boldsymbol{\%})\end{array}$ \\
\hline Television & 36.5 \\
Daily Press & 34.9 \\
Digital Media & 33.3 \\
Radio & 24.5 \\
Specialized and Professional Magazines & 12.2 \\
Newspaper Supplements & 9.2 \\
Magazines & 8.2 \\
Books & 3 \\
Cinema & 1.6 \\
Collectable Fascicles & 0.2 \\
Other Printed Media & 5.3 \\
Other & 6.1 \\
\hline AMP. Annual Report of the Journalistic Profession (2014)
\end{tabular}

During this period after the employment crisis that began in 2008, the journalism profession experienced a very intense process of job insecurity and the creation of new forms of journalistic work, such as the development of digital environments for conventional media, the transformation of journalistic profession into native digital media, and social media journalism.

\subsection{The institutional context of communication research in Spain}

In a similar way to the development of the media system, academic teaching and research in journalism had a late emergence in Spain (even though with a rapid development) during the first

2. http://fape.es/empleo/ 
years of the political transition to Democracy, and linked to the emergence of the first Communication faculties. This institutional and educational context is also the reason why journalism studies is the field with more development and presence in Spanish communication research, especially until the year 2000 and still nowadays but to a lesser extent (Martínez-Nicolás, Saperas \& Carrasco-Campos, 2016).

Therefore, regarding the institutional context for academic research and university education in Spain, the rise of the first university faculties of journalism studies in the early seventies represents a breakthrough for the disciplinary field of communication. These faculties defined a specific space for the higher professional education in journalism, a field which would have a decisive role and social presence during the forthcoming years, in a context of political recognition of the freedom of speech and of the press, the liberalisation of the journalistic and media market, and the development of the Information Society. However, beyond this professional, social and economic role, the universities and the faculties would play, since then, a driving role of the academic activity in the field of communication in both, educational and research dimensions (Jones, 1998; Martínez-Nicolás, 2006 and 2009; Saperas, 2016).

Since then, research on journalism and communication has undergone significant changes in Spain during the first decade of the 21 st century towards a process that could be described as "internationalization". This process, that reaches both the theoretical frameworks of research and the operationalisation procedures of the objects of study that define the usual methodologies applied by research groups in competitive projects and in international field publications, increasingly closer to the standards of scientific production in the United States and Europe. This strategic change in communication research has been decisive, as it can be considered a first step in departing from the specificity of the Spanish case (and even from some of the links to Latin-America), in order to adopt the international hegemonic research standards (Carrasco-Campos \& Saperas, 2014 and 216). The highest expression of this change can be found in three institutional milestones: first, in 2003 with the creation of the National Agency for the Evaluation of Quality and Accreditation (Agencia Nacional de Evaluación de la Calidad y Acreditación - ANECA) (Soriano, 2008), focused on the evaluation of teaching and research activity; second, the approbation in 2008 of the ACADEMIA program for the university teaching habilitation; and third, the beginning of the progressive implementation of the European Higher Education Area (EHEA) in communication studies during 2007/2008, which represents the determined intention to adopt an international academic model common to the European Union, and competitive with other global and expansive university systems, such as the North-American or the Asian and Australian Pacific coast. This trend towards standardisation will progressively go further than the mere normalisation of the professional training developed by universities, to reach the production and diffusion processes of scientific activity, even though in a slow and diverse way regarding the differences found between the universities, the research centers, and even the diverse scientific journals (EscribàSales \& Cortiña-Rovira, 2013; Fernández-Quijada, Masip \& Bergillos, 2013). This work aims to observe and describe statistically journalism research in Spain during this internationalization stage. 


\section{Meta-research: a modality to study how science is performed and results are published}

For the social sciences as a whole, the structure of scientific production has also undergone a great number of transformations because of the variations produced both in the specific demands of knowledge and in the ways in which scientific production and its productivity index are disseminated, organised and evaluated. From an epistemological perspective, and considering this new organisational environment of scientific activity, one of the most significant changes that has occurred in the last two decades refers to the role of peer-reviewed journals, which today can be considered as the dominant institution for the publication of results, for the methodological debate and for the international impact of university centers and researchers (Carrasco-Campos \& Saperas, 2014, pp. 153-154, Carrasco-Campos \& Saperas, 2016). The years between the second half of the 1980s and the first decade of the 2000s have meant the formation and consolidation of a research standard of international scope, fostering a common framework in which peer-reviewed journals and scientific associations have dominated both the disciplinary debate and the criteria of professional reputation of researchers. Therefore, academic journals (more than any other institution) have concentrated the most influential efforts to specify a meta-discourse that defines the discipline and establishes the dominant theoretical and methodological standards. This structural capacity of scientific activity justifies the current interest to study the role of peer-reviewed journals, and to describe the journal articles (papers), representing a preferred line of research for the observation of the interests of knowledge of any community scientifically (Martínez-Nicolás, Saperas \& Carrasco-Campos, 2016).

One of the main novelties in media and journalism studies for the observation of scientific activity and the development of the field has been the introduction of two recent research modalities, but with a certain tradition in other disciplines (especially the biological sciences, medicine and psychology): meta-research and meta-analysis. Following Himter \& Schimidt (2004), from this perspective there are two steps for the accumulation of knowledge: (1) the accumulation of results through individual studies to establish the facts, and (2) the formation of theories (and methodologies) to organise the data in a coherent and useful way. Meta-analysis aims the first stage, while meta-research is oriented to the second step. However, even though both modalities can be considered complementary, they should not be confused neither with "literature review", "benchmarking" or "state of the art", all of them oriented to the organisation and systematisation of knowledge, nor with bibliometric studies based on the statistical description of volume, circulation, dispersion and impact of scientific production (De Bellis, 2009).

Meta-analysis is considered as a research modality focused on the description of the production of knowledge in extended periods of time. This type of work was originally defined by Glass $(1976,1977)$ as a strictly quantitative and statistical procedure, oriented to the exhaustive search and description of all the specialised literature of a specific field, in order to obtain general data without affecting the value or autonomy of each of the original documents and, therefore, allowing the integration of independent studies (Hedges \& Olkin, 1985: 6). In other words, meta-analysis is defined as being a statistical analysis of a large collection of data from a sample of individual studies (Cooper, Hedges \& Valentine, 2009, p. 36). 
On the other hand, the purpose of meta-research is to observe and study research practices by the analysis of research literature. The interest in meta-research arises from the need to systematically study scientific publications, their procedures and their implications in a global economic, technological and social environment and, so, for it is precisely grounded on a model of science of universal scope and with increasing standardisation.

Thus, the capacity of meta-research of generating a systematic knowledge about the research activity published in a field could be helpful to face some of the challenges and the limitations of the present scientific standards, by seeking to observe how the research is carried out, what objects of study define the field, what are the findings achieved, by what techniques, how effectively are they replicated, what is the orientation of the theoretical frameworks, how research techniques are lined to research, how empirical evidences are provided, or how comparative studies are carried out. All of this to analyse if the findings achieved would lead to a coherent corpus instead of disconnected phenomena or results (Frank \& Saxe, 2012: 600-601).

The implementation of meta-research in the social sciences is very recent and began in the mid-1990s (Ioannidis, Fanelli, Dunne \& Goodman, 2015). The most widespread definition was established during the Conference Increasing value and reducing waste in biomedical research ${ }^{3}$, the first international conference on meta-research, focused on the field of biomedicine, which took place in 2015 in Edinburgh. During this event it was agreed that academic journals should be the main object of study of meta-research, as they had become the main agent for the dissemination of scientific production, the definition of the objects of study and dominant models in the fields of pharmacology, medicine and biomedicine. Subsequently, social psychology and experimental psychology incorporated meta-research as an instrument to verify the replication mechanisms, which had suffered an acute crisis during the early 2000s (Earp \& Trafimov, 2015; Everett \& Earp, 2015).

In communication studies, similar to sociology or political science, meta-analysis oriented to statistical description, has undergone a greater development than meta-research (Roelfs, Shor, Falzon, Davidson \& Schwartz, 2013). The elaboration of different indicators and the development of statistical packages and other resources from computational research have made possible the analysis of large data collections, and has allowed meta-analysis to perform efficiently studies of secondary sources and comparative analysis. Despite this greater presence of meta-analysis in the social sciences, meta-research is gradually developing in communication research as a modality for the systematic analysis of the evolution, development and current state of the main theories and fields of research. Meta-research in communication research is being carried out through the study of journal articles published in peer-reviewed journals to study not only some of the theories with greater influence, but also research procedures in emerging fields such as health information and communication, social media in journalism and in civic or in-group discussions, or in crisis communication. Regarding journalism studies, meta-research has a significant presence in the study of the development of great theories such as the agenda setting theory (Tai, 2009;), the notion de framing (Borah, 2011; Saperas \& Carrasco-Campos, 2015) and the cultivation theory,

3. Research Waste/EQUATOR Conference. $28^{\text {th }}-30^{\text {th }}$ September 2015, Edinburgh. www.equator-network.org/ 2015/08/16/research-waste-equator-conference-2015/ 
in this case as a result of the integration of the two modalities (Potter, 2014), and also in the systematic study of recent fields such as social media studies (Baruh, Secinti \& Cemalcilar, 2017), social media journalism (Fu, 2016), health information and communication (Kuang \& Wilson, 2017; Huan \& Shen, 2016; Kuang \& Wilson, 2017) and crisis information (Yang, Aloe \& Feeley, 2014). Therefore, meta-research on journalism provides a new method to analyse how the different professional and academic challenges of journalism during the last decade have been faced by the academics of the discipline (Nielsen, 2017).

\section{Research objectives and method}

This paper aims to study, from a meta-research perspective, the case of Spanish scientific production in journalism studies, by a representative sample of the main Spanish peer-reviewed journals during the period 2000-2014. Specifically, it focuses on the statistical description of the preferred major fields and objects of study developed by researchers (RO1), the research modalities and methods by which research is performed ((RO2), and the specific research techniques applied in journalism research ((RO3).

\subsection{Sample}

A specific content analysis protocol has been designed and applied to a sample of 729 papers published by four Spanish leading journals in the communication discipline: Comunicación y Sociedad (University of Navarra, UNAM), Estudios del Mensaje Periodístico (Complutense University of Madrid, UCM), Anàlisi (Autonomous University of Barcelona (UAB), and ZER (University of the Basque Country, UPV/EHU). These four miscellaneous peer-reviewed journals of communication were selected for responding simultaneously to the following criteria:

- They are the most veteran Spanish journals with the highest rates of "editorial survival" 4 that are currently published in the field of communication: Anàlisi was created in 1980 (38 years), Comunicación y Sociedad has just celebrated its 30th anniversary (1988), Estudios del Mensaje Periodístico was first published in 1994 (24 years), and ZER was created in 1996 (22 years).

- These journals are published by four universities located at the top of the Spanish university rankings, and are part of the four university systems (Autonomous Communities) with the highest rate of scientific production and teaching performance (except those systems that do not offers degrees on communication studies, or those that do not have source peerreviewed journals in the field of communication, preferably Scopus).

- An additional criterion of relevance is that the selected journals are published in the four foundational faculties of communication studies in Spain.

4. The Spanish Information Matrix for the Analysis of Journals (Matriz de Información para el Análisis de Revistas - MIAR), calculates the "editorial survival" rate for a journal by the logarithm of the total life of the journal since the beginning of its publication, considering a maximum of 30 years (for further information, see hrefhttp://miar.ub.edu/abouticdshttp://miar.ub.edu/about-icds). 
- In addition, these four journals have outstanding positions in the most usual Spanish rankings and index during the period of analysis, including the In-RECS index, developed by the University of Granada ${ }^{5}$, and the RESH index of the Higher Council of Scientific Investigations (CSIC) ${ }^{6}$.

From the total sample of 729 articles published during the 15 -years period of analysis, the specific cases on journalism studies ( $\mathrm{N}=360$ articles, $49.4 \%$ of the total sample) were taken to describe the objects of study that embrace this field, the research modalities and the research techniques applied. To preserve the proportionality and homogeneity of the sample, the period 2000-2014 was divided into three five-year periods, of which three years were selected as follows: $2000,2002,2003,2005,2007,2008,2010,2012,2014$. Therefore, the sample includes 9 out of the 15 years studied (60\% of the years). All the papers published by the four selected journals in these years were analysed by applying the coding criteria described below. Even though this design has the limitation of not representing the Spanish communication research overall, the sampling criteria ensures the significance of the results, especially considering the reference character of the selected journals according to the criteria described above.

\subsection{Coding}

Content analysis has been developed by a systematic encoding of 36 variables which allows to observe the structure, methods and techniques that make up a peer-reviewed journal article. This modality of content analysis has been replicated by our research group, developing numerous longitudinal studies on papers published by major Spanish communication journals by means of a wider sample than the selected for this work. For the present study, the period 2000-2014 has been specifically chosen because, according to these previous research, during this stage Spanish communication research has reached a certain maturity and consolidation through a constant adoption of theoretical and methodological standards in international research.

Even though the original coding sheet embraces 36 different variables for a detailed description of communication papers, this work presents results on four of these variables, as follows:

- Research fields: this variable identifies major research fields in communication research and, in addition, specific fields in journalism research.

- Specific objects of study, to observe different research interests in journalism studies papers.

- Research modalities, to distinguish different kinds of methodologies, including empirical (quantitative/qualitative/documentary) and non-empirical (theoretical/methodological) research.

- Research techniques: coding the different specific standard procedures of empirical research for each paper.

The sample was distributed among two coders who were trained in the use of the coding criteria. Ten percent of a random selection of the sample was used to test intercoder reliability (ICR), obtaining 0.71 for Scott's pi. Although it was an optimal value, a double independent encoding

5. http://ec3.ugr.es/in-recs/

6. http://epuc.cchs.csic.es/resh/ 
was applied to the whole sample, discussing any discrepancies that may have occurred until the agreement between coders. Therefore, because of this systematic application of quantitative content analysis protocols, the results of this work must be considered highly reliable.

\section{Results}

\subsection{Research fields in communication and journalism studies}

Journalism stands as the major research field in the current stage of consolidation and internationalisation of Spanish communication research (table 2). Almost half $(49,4 \%)$ of the analysed papers during the period 2000-2014 address journalism studies topics such as news coverage analysis, the study of journalistic professionalism, journalism and digital media, etc. These outputs are especially relevant if we consider that journalism studies represents more than double the second category with more representation: media studies (22.9\%), a broad field which embraces topics regarding audio-visual communication, such as television studies, cinema studies, radio studies, etc. Other research fields are very limited, both classic fields such as mass-media communication $(7.5 \%)$ or advertisement $(4.8 \%)$, and emerging fields such as public relations $(8.1 \%)$ or internet studies (4.9\%).

Table 2. Major research fields in communication

\begin{tabular}{lcc}
\hline Research fields & $\begin{array}{c}\text { Frequency } \\
(\mathbf{N = 7 2 9 )}\end{array}$ & $\begin{array}{c}\text { Percentage } \\
(\%)\end{array}$ \\
\hline Journalism Studies & 360 & 49,4 \\
Media Studies & 167 & 22,9 \\
Public Relations and Marketing Communications & 59 & 8,1 \\
Communication/Mass Media Communication (in general) & 55 & 7,5 \\
Internet and Digital Media Studies & 36 & 4,9 \\
Advertisement & 35 & 4,8 \\
Institutional and Political Propaganda & 7 & 1 \\
Other & 9 & 1,2 \\
\hline
\end{tabular}

Regarding the specific research fields in journalism studies (table 3), the analysis reveals three broad categories: print journalism (35.8\%); journalism, press and journalistic professionalism (32\%), and digital and social media journalism (15.2\%). These three fields embrace almost the entirety of the analysed journalism studies papers, summing up to $83 \%$. A close analysis on these fields shows that the studies on daily press journalism are the most usual, representing almost a third part of the analysed papers. The relevance of this field should be compared to other conventional areas, which are very limited as they do not even reach the $10 \%$ level. This is the case for television journalism (8.9\%), non-daily press journalism (3.3\%) or radio journalism (1.9\%). Studies on daily press journalism are also very dominant compared to papers on emerging forms of journalism, such as digital media journalism (12.2\%), social media journalism (1.9\%) and citizen journalism $(1.1 \%)$. However, this field related to the technological changes of the profession seem to be an increasing research interest for Spanish scholars, considering that in the nineties, 
studies on journalism and the internet were practically non-existent (Martínez-Nicolás, Saperas \& Carrasco-Campos, 2017). On the contrary, research focused on general topics of journalism are also relevant, summing up to $32 \%$ of the analysed papers. According to this, the studies on journalism, the press and professional cultures stands as a main interest for Spanish researchers in a period of continuous changes in the profession and in the media system due to the globalisation of communications and to the digitalisation of the professional activity.

Table 3. Specific research fields in journalism

\begin{tabular}{|c|c|c|c|}
\hline \multicolumn{2}{|l|}{ Research fields } & $\begin{array}{c}\text { Frequency } \\
(\mathbf{N}=399)\end{array}$ & $\begin{array}{c}\text { Percentage } \\
(\%)\end{array}$ \\
\hline \multirow{3}{*}{ Print Journalism } & Daily press journalism & 117 & 32,5 \\
\hline & Non-daily press journalism & 12 & 3,3 \\
\hline & Total & 129 & 35,8 \\
\hline \multirow{4}{*}{ Journalism, Press and Professional Cultures } & Journalism (in general) & 102 & 28,3 \\
\hline & Press (in general) & 11 & 3,1 \\
\hline & News agencies (in general) & 2 & 0,6 \\
\hline & Total & 115 & 32 \\
\hline \multirow{4}{*}{ Social Media and Digital Journalism } & Digital media journalism & 44 & 12,2 \\
\hline & Social media journalism & 7 & 1,9 \\
\hline & Citizen journalism & 4 & 1,1 \\
\hline & Total & 55 & 15,2 \\
\hline TV Journalism & & 32 & 8,9 \\
\hline Journalism Research and Education & & 13 & 3,6 \\
\hline Radio Journalism & & 7 & 1,9 \\
\hline Infographics & & 5 & 1,4 \\
\hline Photojournalism & & 3 & 0,8 \\
\hline Comicjournalism & & 1 & 0,3 \\
\hline
\end{tabular}

Data on specific objects of study in journalism (table 4) are consistent to the observations on research fields, as they show a great interest in news content research (58.9\%). Studies on the intuitional dimension of journalism (professionalism, 22.1\%; and institutions and companies, $8.8 \%$ ) are also relevant, but minor in comparison to those focused on the discursive dimension. Hence, research on journalistic contents, journalistic professionalism and media systems embraces the great majority of the academic interests for Spanish scholars (these three categories sum up to $89.8 \%$ of the analysed objects of study). On the contrary, data indicates a little interest in the studies on the social dimension of journalism, as research on audiences (5.5\%) and on the effects and influence of news $(1 \%)$ are very limited. 
Table 4. Specific objects of study in journalism

\begin{tabular}{lcc}
\hline Objects of study & $\begin{array}{c}\text { Frequency* } \\
(\mathbf{N = 3 9 9 )}\end{array}$ & $\begin{array}{c}\text { Percentage } \\
(\%) *\end{array}$ \\
\hline Contents & 235 & 58,9 \\
Professionalism & 88 & 22,1 \\
Institutions and Companies & 35 & 8,8 \\
Audiences and Reception & 22 & 5,5 \\
Journalism Education & 12 & 3 \\
Effects & 4 & 1 \\
Technologies & 1 & 0,3 \\
Journalism Research & 1 & 0,3 \\
Journalism (in general) & 1 & 0,3
\end{tabular}

* For each of the analised papers were encoded all the objects of study detected. Percentages are calculated from the total number of specific journalistic objects of study observed ( $\mathrm{N}=399$ objects of study).

\subsection{Research modalities and techniques in journalism research}

The analysis of research modalities (table 5) confirms that journalism studies in nowadays communication research in Spain is mostly performed by empirical studies, as that represents the $83.7 \%$ of the analysed papers. Moreover, theoretical (14.4\%) and methodological (1.9\%) studies are very scarce. According to previous studies, during the 1990s journalism research, similarly to the whole of communication research, would have experienced a stage of theoretical debate regarding the demands of knowledge raised because of the development of the academic and of the media system (Martínez-Nicolás, Saperas \& Carrasco-Campos, 2017, Carrasco-Campos, Saperas \& Martínez-Nicolás, 2018). To this respect, the results would point to a certain consolidation of journalism studies as an empiric programme, especially in terms of quantitative research $(28.1 \%)$, or even documentary research (that is, empirical studies focused on the description of institutional or professional documents, which represents the $25.3 \%$ of the cases), while qualitative studies are very limited. However, this empiric stage would still lack methodological maturity and sophistication, as a quarter of the analysed papers $(25.3 \%)$ do not have an explicit description of the empirical research procedures, or even the implementation of any specific research technique. 
Journalism research: a dominant field of communication research in Spain. A meta-research on Spanish...

Table 5. Research modalities in journalism

\begin{tabular}{|c|c|c|c|}
\hline Research modalities & & $\begin{array}{c}\text { Frequency } \\
(\mathbf{N}=360)\end{array}$ & $\begin{array}{c}\text { Percentage } \\
(\%)\end{array}$ \\
\hline \multirow{6}{*}{ Empirical Research } & Quantitative & 101 & 28,1 \\
\hline & Non-explicit description of research procedures & 91 & 25,3 \\
\hline & Documentary & 54 & 15 \\
\hline & Qualitative & 33 & 9,2 \\
\hline & Quantitative and qualitative & 22 & 6,1 \\
\hline & Total & 301 & 83,7 \\
\hline \multirow{3}{*}{ Theoretical Research } & Theoretical & 52 & 14,4 \\
\hline & Methodological & 7 & 1,9 \\
\hline & Total & 59 & 16,3 \\
\hline
\end{tabular}

The combined observation of research modalities and fields (table 6) reveals some specific similarities and differences. Thus, while the use of empirical research procedures without an explicit description of the techniques employed is usual in the three major fields of journalism studies, theoretical and documentary studies are common in journalism and professional cultures in general, while quantitative research is frequent in print journalism and in digital and social media journalism. The case of papers on TV journalism are an interesting exception as these studies, even being limited (only 32 cases were identified), they show less dispersion on research modalities compared to other major fields.

Table 6. Research fields and research modalities in journalism studies (\%*)

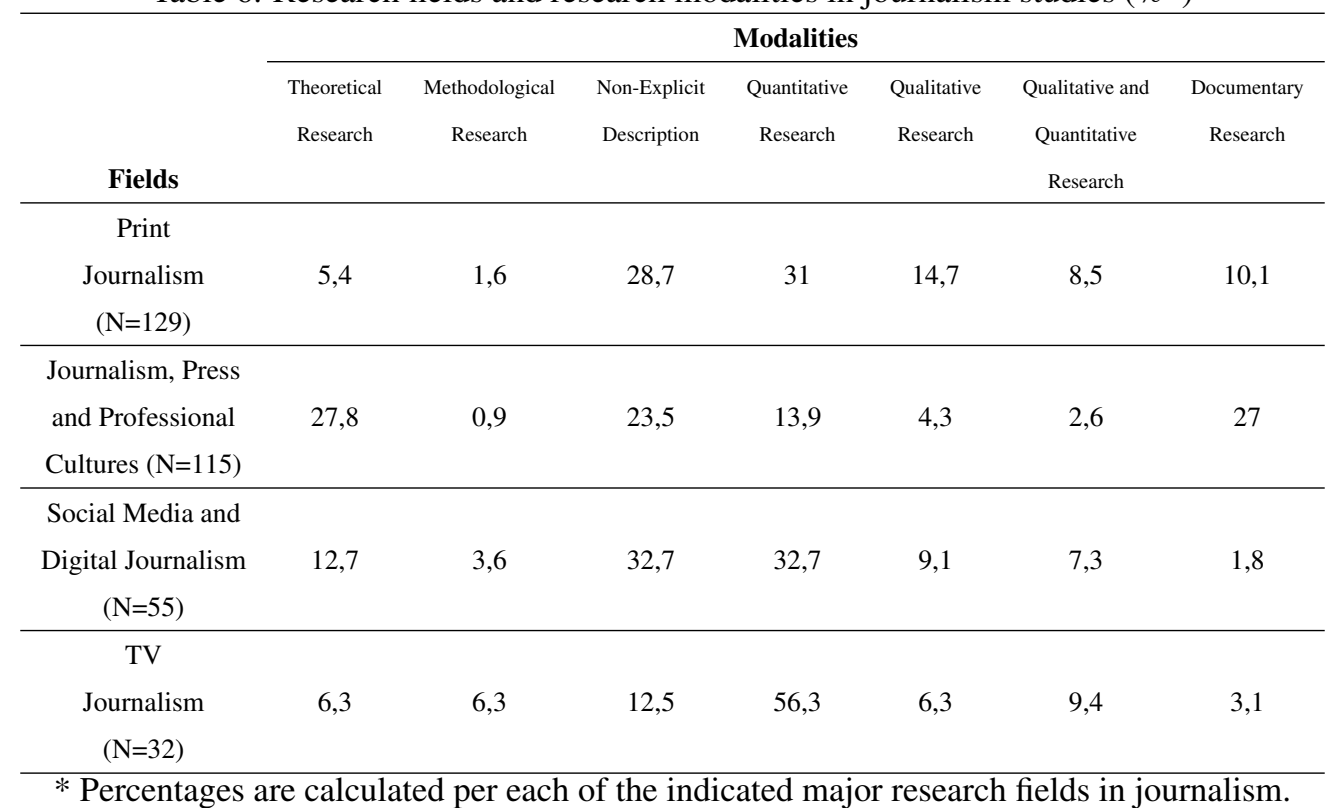

The data on research techniques for the cases of journalism studies performed by standard empirical research (quantitative, qualitative and documentary studies) (table 7) are consistent to 
the previous analysis of the pre-eminence of content studies and of quantitative studies, as more than a third of the techniques employed refer to quantitative content analysis (38.5\%). Other techniques regarding contents and discourses analysis, such as documentary research $(21.8 \%)$ and qualitative discourse analysis $(11.1 \%)$ are also relevant. On the contrary, studies on living sources (i.e. surveys, interviews, experimental research, or observation) are very limited. A similar presence of qualitative interviews $(9.1 \%)$ and surveys $(8.7 \%)$ is observed, while other qualitative procedures (such as ethnographic observation, focus groups, experimental research and Delphi studies) are the minority. Data on experimental research are also relevant, as they are very scarce (1.2\%; only three cases were identified).

Table 7. Standard research techniques in journalism

\begin{tabular}{lcc}
\hline Research techniques & $\begin{array}{c}\text { Frequency* } \\
\text { (N=252) }\end{array}$ & $\begin{array}{c}\text { Percentage* } \\
(\%)\end{array}$ \\
\hline Quantitative Content Analysis & 97 & 38,5 \\
Documentary Sources Analysis & 55 & 21,8 \\
Discourse Analisys & 28 & 11,1 \\
Qualitative Interview & 23 & 9,1 \\
Survey & 22 & 8,7 \\
Secondary Sources Research & 11 & 4,4 \\
Observation & 6 & 2,4 \\
Focus Group & 5 & 2 \\
Experimental Research & 3 & 1,2 \\
Delphi & 1 & 0,4 \\
Other & 1 & 0,4
\end{tabular}

* For each of the analysed papers were encoded all the research techniques detected. Percentages are calculated from the total number of standard reserch techniques observed ( $\mathrm{N}=252$ research techniques).

However, a more detailed analysis combining research techniques and major fields of journalism studies (table 8) shows some differences. In this case, the general field of journalism, press and professional cultures is the exception, as documentary research is the most usual technique (considering the cases of systematic research of laws, code of ethics, historical documents, professional or institutional reports, etc.), followed by surveys mainly applied to professionals. Quantitative content analysis is the most representative technique for the other major fields, especially in the case of TV journalism which, once again, reveals to be a limited field but with a high level of methodological standardisation. Print journalism shows the previously observed preeminence of content discourse by means of quantitative content analysis and, to a lesser extent, of qualitative discourse analysis. 
Journalism research: a dominant field of communication research in Spain. A meta-research on Spanish...

Table 8. Research fields and research techniques in journalism studies (\%*)

\begin{tabular}{|c|c|c|c|c|c|c|c|c|}
\hline \multirow[b]{2}{*}{ Fields } & \multicolumn{8}{|c|}{ Modalities } \\
\hline & $\begin{array}{c}\text { Experimental } \\
\text { Research }\end{array}$ & Survey & $\begin{array}{l}\text { Content } \\
\text { Analysis }\end{array}$ & $\begin{array}{l}\text { Discourse } \\
\text { Analysis }\end{array}$ & $\begin{array}{l}\text { Qualitative } \\
\text { Interviews }\end{array}$ & $\begin{array}{l}\text { Focus } \\
\text { Group }\end{array}$ & $\begin{array}{c}\text { Secondary } \\
\text { Sources }\end{array}$ & $\begin{array}{c}\text { Documentary } \\
\text { Sources }\end{array}$ \\
\hline $\begin{array}{c}\text { Print } \\
\text { Journalism } \\
(\mathrm{N}=98)\end{array}$ & 1 & 1 & 50 & 21,4 & 5,1 & 2 & 4,1 & 13,3 \\
\hline $\begin{array}{l}\text { Journalism, Press } \\
\text { and Professional } \\
\text { Cultures }(\mathrm{N}=62)\end{array}$ & 0 & 22,6 & 6,5 & 1,6 & 11,3 & 3,2 & 4,8 & 50 \\
\hline $\begin{array}{l}\text { Social Media and } \\
\text { Digital Journalism } \\
\quad(\mathrm{N}=40)\end{array}$ & 2,5 & 7,5 & 45 & 5 & 20 & 0 & 5 & 5 \\
\hline $\begin{array}{c}\text { TV } \\
\text { Journalism } \\
(\mathrm{N}=29)\end{array}$ & 0 & 6,9 & 65,5 & 6,9 & 6,9 & 3,4 & 0 & 0 \\
\hline
\end{tabular}

\section{Discussion and conclusions}

This work aimed to describe how scholars perform journalism research in Spain, during the period of 15 years (2000-2014). This period is characterised by the consolidation of the field as a dominant research field. For this purpose, a content analysis was applied to a sample of 729 papers published by leading Spanish peer-reviewed journals of communication. Although the methodological design of this study has not made possible the study of the entire production of journalism research during the period of analysis, the selection of the four miscellaneous peerreviewed journals with more tradition, historical relevance and scientific impact for the scholar community ensures the significance of the results. Previous research on this topic has focused on longitudinal studies of the evolution of communication studies, on which several descriptions of the past, present and the evolution of media research and journalism research were provided. However, for this work the decision was to analyse a whole period of 15 years on the whole to shape a statistical description of current Spanish research on journalism studies. The analysis of the delimitation of journalism as a field has been provided by the observation of the major research fields and the objects of study. Therefore, the results reveal not only the importance of journalism studies in Spanish communication research, but also (and more specifically) the relevance of studies on daily press journalism and the rise of digital media journalism. The analysis of specific objects of study indicated the predominance of studies on journalistic contents, as well as a certain importance of the research on the professional and institutional aspects of journalism, while the papers on audiences and effects were in the minority.

Methodological aspects of journalism research were analysed in more detail, since these are decisive elements to assess the maturity level of the discipline, and the adoption of a research standard of international validity. A minor presence of theoretical and methodological works 
was confirmed, as well as the pre-eminence of empirical research. Both observations can be interpreted as indicators of the theoretical consolidation of the field after years of a more intense conceptual discussion that we observed in previous works. However, even being greater than in previous stages, the systematicity of these empirical works is still insufficient, since a quarter of the analysed papers were still performed without a detailed methodological description or lacking standardised techniques. The standard techniques with a greater presence in this period of analysis were the quantitative content analysis and the documentary research, which should be considered as the characteristic methods for journalism studies in Spain. These techniques were especially relevant for research on print journalism; a field that nonetheless referred to a high percentage of research without methodological description. In addition, data regarding digital journalism and social media journalism is also relevant, as these fields used not only the content analysis, but also qualitative interviews. On the other hand, the general field of journalism, press and professional cultures research showed the greatest diversity since it revealed a similar presence of theoretical studies, documentary research, papers performed by content analysis and, to a lesser extent, by surveys.

Therefore, and in sum, we can conclude that even though Spanish journalism research is a dominant field in communication, it is mainly descriptive and with a lack of theoretical discussion or even with no definition of theoretical frameworks, which is performed by empirical modalities (mostly by quantitative techniques, but also without systematic methodologies).

Regarding the objects of study, a certain homogeneity has also been observed. Journalistic contents and, although to a lesser extent, studies on the profession are the main objects observed, with a scarce presence of studies focused on the social dimensions of journalism (audiences, effects), on technological aspects and its consequences in the transformation of journalism. In addition, the pre-eminence of content analysis and documentary analysis, as well as the significant presence of non-systematic research, reveals a certain lack of diversity not only concerning the objects of study, but also the research techniques, with a very limited presence of qualitative research, experimental research, surveys and research by secondary sources.

Lastly, these considerations on the achieved results may suggest lines for future research. For instance, it would be relevant to perform comparative studies on the dominant interest of knowledge of journalism research published by Spanish peer-reviewed journals and the structural changes experienced by the media system and the journalism profession during the period 20002014 that were described in the introduction: the progressive universal access to the Internet and the rise of second screens, the changes in media consumption habits, the formation of a polarizedpluralism model grounded on the consolidation of an intense political parallelism, and the crisis and uncertainty of the labour market of journalism. A comparative analysis regarding the research fields, the media penetration (chart 1) and the distribution of journalistic profession in the media, in both digital and traditional environments (table 1) would also be relevant. The possible lack of correlation between the academic interests of knowledge, the structure of consumption in audiences and the distribution of professionals in journalistic companies might also occur in other university and research systems. However, for the moment we lack specific data to confirm that hypothesis. Similarly, other suggestions for future research derived from this work would be an 
in-depth analysis of the development and operationalisation tendencies of an emerging field such as journalism in digital environments, and the informative uses of smartphones and social media.

\section{References}

AIMC (2014). Estudio general de medios. Resumen general (febrero a noviembre de 2014). Madrid: AIMC. Retrieved from: www.aimc.es/a1mc-c0nt3nt/uploads/2014/12/resumegm314. pdf

Baruh, L.; Secinti, E. \& Cemalcilar, Z. (2017). Online privacy concerns and privacy management: a meta-analytical review. Journal of Communcation, 67(1), 26-53.

Borah, P. (2011). Conceptual issues in framing theory. A systematic examination of a decade's literature. Journal of Communication, 61(2), 246-263.

Calcutt, A. \& Hammond, P. (2011). Journalism studies. A critical introduction. New York: Routledge.

Carrasco-Campos, Á. \& Saperas, E. (2014). Debate, confrontación y hegemonía en la disciplina de la comunicación. Nuevos tiempos para un paradigma dominante. Revista Redes.com, 10.

Carrasco-Campos, Á. \& Saperas, E. (2016). Cambio tecnológico, globalización neoliberal y hegemonías metodológicas en la investigación comunicativa internacional. Ámbitos. Revista Internacional de Comunicación, 32.

Carrasco-Campos, Á.; Saperas, E. \& Martínez-Nicolás, M. (2018). ¿Cómo investigamos la comunicación en España? Universidades públicas y privadas en las publicaciones científicas de comunicación españolas (1990-2014). adComunica, 15.

Casero, A. (2012). El periodismo político en España: algunas características definitorias. In A. Casero (ed.), Periodismo político en España: concepciones, tensiones y elecciones. Tenerife: Sociedad Latina de Comunicación Social.

Cooper, H.; Hedges, L. V. \& Valentine, J. C. (2009). The handbook of research synthesis and meta-analysis (2nd ed.). New York: Russell Sage Foundation.

Earp, B.D. \& Trafimov, D. (2015). Replication, falsification and the crisis of confidence in social psychology. Frontiers on Psychology, 6. doi:10.3389/fpsyg.2015.0062.

De Bellis, N. (2009). Bibliometrics and citation analysis: from the science citation index to cybermetrics. Toronto: Scarecrow.

Escribà-Sales, E. \& Cortiña-Rovira, S. (2013). La internacionalización y las coautorías en las principales revistas científicas de comunicación en España. Comunicar, 41.

Everett J. A. C. \& Earp, B. D. (2015). A tragedy of the (academic) commons: interpreting the replication crisis in psychology as a social dilemma for early-career researchers. Frontiers on Psychology, 6. doi: 10.3389/fpsyg.2015.01152.

FAPE (2014). Informe anual de la profesión periodística, 2014. Madrid: Asociación de la prensa de Madrid. Recuperado: http://www.apmadrid.es/publicaciones/informe-anual-de-laprofesion 
Fernández-Quijada, D.; Masip, P. \& Bergillos, I. (2013). El precio de la internacionalidad: la dualidad en los patrones de publicación de los investigadores españoles en comunicación. Revista española de documentación científica, 36(2).

Frank, M. C. \& Saxe, R. (2012). Teaching replication. Perspectives on Psychological Science, $7(6)$.

Franklin, B. (2010). Introduction to issue 4: the future of journalism. Journalism Studies, 11(4).

$\mathrm{Fu}, \mathrm{S}$. J. (2016). Leveraging Social Network Analysis for research on journalism in the information age. Journal of Communication, 66(2), 299-313.

Glass, G. V. (1976). Primary, secondary and meta-analysis of research. Educational Research, 3, 3-8.

Glass, G. V. (1977). Integrating findings. The meta-analysis of research. Review of Research in Education, (5), 351-379.

González, J. J. \& Novo, A. (2011). The role of the media agenda in a context of political polarization. Communication \& Society, 24(2).

Hallin, D. \& Mancini, P. (2004). Comparing media systems. Three models of media and politics. Cambridge: Cambridge University Press.

Hedges, L. V. \& Olkin, I. (1985). Statistical methods for meta-analysis. Orlando (FL): Academic Press.

Huang, Y. \& Shen, G. (2016). Effects of cultural tailoring on persuasion in cancer communication. A meta-analysis. Journal of Communication, 66(4), 694-715.

Hunter, J. E. \& Schmidt, F. L. (2004). Methods of meta-analysis. Correcting error and bias in research findings. Thousand Oaks (California): Sage.

Ioannidis, J. P. A.; Fanelli, D.; Dunne, D. D. \& Goodman, S. N. (2015). Meta-research: evaluation and improvement of research methods and practices. PLoS Biol., 13(10).

Jones, D. E. (1998). Investigación sobre comunicación en España: evolución y prespectivas. Revista Zer, 3(5).

Kuang, K. \& Wilson, S.R. (2017). A meta-analysis of uncertainty and information management in illness contexts. Journal of Communication, 67(3): 378-401.

López-Rabadán, P. \& Casero, A. (2012). La evolución de la agenda mediática española (19802010). Un análisis longitudinal de la portada de la prensa de referencia. Revista Latina de Comunicación Social, 67.

Martínez-Nicolás, M. (2006). Masa (en situación) crítica. La investigación sobre periodismo en España: comunidad científica e intereses de conocimient. Anàlisi, 33.

Martínez-Nicolás, M. (2009). La investigación sobre comunicación en España. Evolución histórica y retos actuales. Revista Latina de Comunicación Social, 64.

Martínez-Nicolás, M.; Humanes, M. L. \& Saperas E. (2014). La mediatización de la política en el periodismo español. Análisis longitudinal de la información política en la prensa de referencia (1980-2010). Trípodos, 34. 
Martínez-Nicolás, M. \& Saperas, E. (2011). La investigación sobre Comunicación en España (1998-2007). Análisis de los artículos publicados en revistas científicas. Revista Latina de Comunicación Social, 66.

Martínez-Nicolás, M.; Saperas, E. \& Carrasco-Campos, Á. (2016). Research focus and methods in Spanish Communication Studies. A longitudinal content analysis of five top Spanish journals. 6th European Communication Conference (ECREA). Prague, 9th-12th November.

Martínez-Nicolás, M.; Saperas, E. \& Carrasco-Campos, Á. (2017). Journalism studies in Spain. An analysis of the papers published in Spanish journals over the last 25 years. Communication \& Society, 30(4).

Mellado, C.; Humanes, M. L. \& Márquez-Ramírez, M. (2017). The influence of journalistic role performance on objective reporting: a comparative study of Chilean, Mexican, and Spanish news. International Communication Gazette, 79(4).

Ministerio de Economía y Competitividad. (2017). Informe de situación de la economía española2017. Madrid: Publicaciones del Ministerio de Economía y Competitividad.

Nielsen, R. K. (2017). What is journalism studies studying? [blog post: 2017, September 14th] rasmuskleisnielsen.net. Retrieved from: https://rasmuskleisnielsen.net/2017/09/14/what-isjournalism-studies-studying/

Ortega, F. (2003). Periodistas y políticos. Una simbiosis compleja. Telos, 54.

Potter, W. J. (2014). A critical analysis of cultivation theory. Journal of Communication, 64(6), 1015-1036.

Roelfs, D. J.; Shor, E.; Falzon, L.; Davidson, K. W. \& Schwartz, J. E. (2013). Meta-analysis for sociology. A measure-driven approach. Bulletin of Sociological Methodology, 117, 75-92.

Saperas, E. (2016). Cuatro décadas de investigación comunicativa en España. Los procesos de institucionalización y profesionalización de la investigación (1971-2015). Disertaciones, 9(2).

Saperas, E. \& Carrasco-Campos, Á. (2015). The operationalization of the concept of framing in the Journal of Communication (2009-2013): objects of study, research techniques and theoretical construction. Communication \& Society, 28(4).

Soriano, J. (2008). El efecto ANECA. Actas y memoria final del Congreso internacional fundacional AE-IC. Santiago de Compostela, 29 enero de 2008.

Tai, Z. (2009). The structure of knowledge and dynamics of scholarly communication in agenda setting research, 1996-2005. Journal of Communication. 59(3), 481-513.

U Ranking (2018). U Ranking Universidades españolas, 2017. Retrieved from: www.u-ranking.es /analisis.php

Van Dalen., A. (2012). The people behind the political headlines. A comparison of political journalists in Denmark, Germany, the United Kingdom and Spain. The International Communication Gazette, 74(5).

Van Dalen, A.; De Vreese, C. H. \& Albæk, E. (2012). Different roles, different content? A four-country comparison of the role conceptions and reporting style of political journalists. Journalism, 13(7). 
Yang, A. J.; Aloe, A. M. \& Feeley, Th. H. (2014). Risk information seeking and processing model. A meta-analysis. Journal of Communication, 64(1), 20-41. 